\title{
Detection of S-100ß Protein in Plasma and Urine After a Mild Traumatic Brain Injury
}

\author{
Natalie Le Sage (iD, Pier-Alexandre Tardif(D), Jérôme Frenette, Marcel Émond, \\ Jean-Marc Chauny, Lynne Moore, Patrick Archambault, Jeffrey Perry, \\ Antoine Boulanger-Piette
}

\begin{abstract}
This study assessed whether S-100 $\beta$ protein could be measured in urine when detectable in plasma after a mild traumatic brain injury (mTBI). Clinical data, plasma and urine samples were collected for the 46 adult patients prospectively enrolled in the emergency department (ED) of a Level 1 trauma center. S- $100 \beta$ protein concentrations were analysed using ELISA. S-100 $\beta$ protein was detectable in $91 \%$ and $71 \%$ of plasma and urine samples, but values were not correlated $(r=0.002)$. Urine sampling would have been a non-invasive procedure, but it does not appear to be useful in the ED during the acute phase after an mTBI.

RÉSUMÉ : Détection de la protéine S-100 $\beta$ dans le plasma et l'urine à la suite d'un traumatisme cranio-cérébral léger (TCCL). Cette étude a cherché à évaluer dans quelle mesure la teneur en protéine S-100 $\beta$ peut être mesurée dans l'urine après avoir été détectée dans le plasma, et ce, à la suite d'un TCCL. Des données cliniques ainsi que des échantillons de plasma et d'urine ont alors été collectés chez quarante-six patients adultes recrutés de façon prospective dans le service d'urgence d'un centre tertiaire de traumatologie. La teneur en protéine S-100 $\beta$ a été analysée au moyen de la méthode immuno-enzymatique ELISA. La protéine S-100 $\beta$ s'est avérée détectable dans respectivement $91 \%$ et $71 \%$ des échantillons de plasma et d'urine. Cela dit, les valeurs obtenues ne sont pas apparues corrélées $(\mathrm{r}=0,002)$. Le fait de recourir à des échantillons d'urine aurait pu représenter une procédure noninvasive ; cependant, elle ne semble pas utile dans un service d'urgence lors de la phase aigüe consécutive à un TCCL.
\end{abstract}

Keywords: Brain injury - Traumatic, Trauma, Biomarkers, Neuroimaging, Head trauma

doi:10.1017/cjn.2019.61

Can J Neurol Sci. 2019; 46: 599-602

Mild traumatic brain injury (mTBI) is a frequent reason for consultation in the emergency department (ED). In Canada, the incidence of mTBI is estimated at 500-600 cases per 100,000 person-years. ${ }^{1}$ In order to refine current clinical decision rules to avoid unnecessary CT scans or identify patients at risk of post-concussion symptoms (PCS), a number of biomarkers have been evaluated, notably S-100 $\beta$ protein. ${ }^{2} \mathrm{~S}-100 \beta$ is a calciumbinding protein found in neural and non-neural tissues and is thought to participate in the regulation of cellular calcium homeostasis and other biological processes such as cell proliferation, differentiation and survival. ${ }^{3}$ Serum levels of S-100 $\beta$ protein seem to be increased following a traumatic brain injury (TBI). ${ }^{4}$ Since this is a possible association between intracranial injury and S-100 $\beta$ protein, this protein was suggested as a biomarker by the American College of Emergency Physicians ${ }^{5}$ and Scandinavian Neurotrauma Committee CT guidelines ${ }^{6}$ in order to avoid unnecessary CT scans in patients with an mTBI presenting low levels of S-100 $\beta$ serum levels $(<0.10 \mu \mathrm{g} / \mathrm{L}$ or $100 \mathrm{pg} / \mathrm{mL})$ within 4-6 h of injury.

Injury biomarkers such as S-100 $\beta$ protein have been reported to be detectable in urine, ${ }^{4}$ cerebrospinal fluid (CSF) and serum after a TBI. ${ }^{7}$ Serum samples are not routinely taken in patients with mTBI. Urine samples are non-invasive and would be less burdensome in busy settings. However, we do not know if the concentration and stability of S-100 $\beta$ protein would interfere with its clinical use. In severe TBI, although S-100 $\beta$ protein levels were detectable in urine, their prognostic values (sensitivity, specificity, negative and positive predictive values) and capacity to discriminate between patients who survived or not a month following injury were systematically poorer than serum levels. ${ }^{2}$ Moreover, the best cut-off values for serum and urine levels were $0.461 \mu \mathrm{g} / \mathrm{L}(461 \mathrm{pg} / \mathrm{mL})$ and $0.025 \mu \mathrm{g} / \mathrm{L}(25.1 \mathrm{pg} / \mathrm{mL})$ respectively, ${ }^{2}$ suggesting that urine levels are considerably lower

From the Population Health and Optimal Health Practices, CHU de Québec Université Laval Research Center, Québec, QC, Canada (NLS, P-AT, ME, LM); Département de Médecine Familiale et Médecine d'Urgence, Faculté de Médecine, Université Laval, Québec, QC, Canada (NLS, ME, PA); Centre Hospitalier Universitaire de QuébecCentre de Recherche du Centre Hospitalier de l'Université Laval, Université Laval, Québec, QC, Canada (JF, PA, AB-P); Centre d'Excellence sur le Vieillissement de Québec, Centre de recherche sur les soins et les services de première ligne de l'Université Laval, Québec, QC, Canada (ME); Hôpital du Sacré-Cœur de Montréal, Montréal, QC, Canada (J-MC); Département de médecine familiale et médecine d'urgence, Université de Montréal, Montréal, QC, Canada (J-MC); Centre intégré de santé et services sociaux de Chaudière-Appalaches, Hôtel-Dieu de Lévis, Lévis, QC, Canada (PA); Department of Emergency Medicine, University of Ottawa and Ottawa Hospital Research Institute, Ottawa, ON, Canada (JP)

Received August 30, 2018. Final Revisions Submitted April 5, 2019. Date of ACCEPTANCE April 30, 2019.

Correspondence to: Natalie Le Sage, CHU de Québec - Université Laval Research Center, Université Laval , 1401, $18^{\mathrm{e}}$ rue, Québec, QC G1J 1Z4, Canada. Email: natalie. lesage@fmed.ulaval.ca 
Table 1: Clinical and sociodemographic characteristics of patients $(n=46)$

\begin{tabular}{|c|c|c|c|c|}
\hline Variables & Categories & $N(\%)$ & Plasma $^{\text {b,c }}$ & Urine $^{b, c}$ \\
\hline \multirow[t]{3}{*}{ Age (years) } & $14-34$ & $30(65.2)$ & $28(93.3)$ & $21(70.0)$ \\
\hline & $35-54$ & $7(15.2)$ & $7(100.0)$ & $4(57.1)$ \\
\hline & $\geq 55$ & $9(19.6)$ & $8(88.9)$ & $8(88.9)$ \\
\hline \multirow[t]{2}{*}{ Sex } & Male & $33(71.7)$ & $32(96.9)$ & $25(75.8)$ \\
\hline & Female & $13(28.3)$ & $11(84.6)$ & $8(61.5)$ \\
\hline \multirow[t]{3}{*}{ Loss of consciousness } & No & $13(28.9)$ & $13(100.0)$ & $11(84.6)$ \\
\hline & Yes & $21(46.7)$ & $20(85.2)$ & $14(66.7)$ \\
\hline & Don’t know & $11(24.4)$ & $9(81.8)$ & $8(72.7)$ \\
\hline \multirow[t]{5}{*}{ Anterograde amnesia } & No & 19 (41.3) & $19(100.0)$ & $10(52.6)$ \\
\hline & $<30$ minutes & $10(21.7)$ & $10(100.0)$ & $8(80.0)$ \\
\hline & $\geq 30$ minutes $<3 \mathrm{~h}$ & $1(2.2)$ & $1(100.0)$ & $1(100.0)$ \\
\hline & $\geq 3 \mathrm{~h}$ & $0(0.0)$ & - & - \\
\hline & Yes but unknown duration & $16(34.8)$ & $13(81.3)$ & $14(87.5)$ \\
\hline \multirow[t]{4}{*}{ Retrograde amnesia } & No & $31(67.4)$ & $22(70.9)$ & $22(70.9)$ \\
\hline & $<30$ minutes & $5(10.9)$ & $4(80.0)$ & $4(80.0)$ \\
\hline & $\geq 30$ minutes & $2(4.4)$ & $2(100.0)$ & $2(100.0)$ \\
\hline & Yes but unknown duration & $8(17.4)$ & $5(62.5)$ & $5(62.5)$ \\
\hline \multirow[t]{3}{*}{ Glasgow Coma Scale $^{\mathrm{a}}$} & 13 & $0(0.0)$ & - & - \\
\hline & 14 & $6(13.0)$ & $5(83.3)$ & $4(66.7)$ \\
\hline & 15 & $40(87.0)$ & $38(95.0)$ & $29(72.5)$ \\
\hline \multirow[t]{4}{*}{ Mechanism of injury } & Sport & $16(34.8)$ & $15(93.8)$ & $9(56.3)$ \\
\hline & Motor vehicle accident & $7(15.2)$ & $6(85.7)$ & $6(85.7)$ \\
\hline & Fall from elevation ( $\geq 3$ feet $/ 5$ stairs & $4(8.7)$ & $4(100.0)$ & $4(100.0)$ \\
\hline & Other types of injury & $19(41.3)$ & $18(94.7)$ & $14(73.4)$ \\
\hline Concomitant injuries & Presence of $\geq 1$ concomitant injury & $20(48.8)$ & $17(85.0)$ & $16(80.0)$ \\
\hline
\end{tabular}

${ }^{\mathrm{a}}$ Score on arrival at emergency department.

${ }^{\mathrm{b}}$ Detectable values in plasma $(n=42)$ and urine $(n=33)$ samples, $n(\%)$.

${ }^{\mathrm{c}}$ Limit of detection: plasma $>2.7 \mathrm{pg} / \mathrm{mL}$, urine $>15.6 \mathrm{pg} / \mathrm{mL}$.

than serum levels. The utility of $S-100 \beta$ protein levels in urine remains unclear and warrants further evaluation, ${ }^{8}$ notably in mTBI patients.

In this study, we aimed (1) to determine if $S-100 \beta$ protein was detectable during the acute phase in urine samples of patients who suffered an mTBI and presented at the ED, notably when it was detectable in plasma samples using commonly found EnzymeLinked Immunosorbent Assay (ELISA) technology; (2) to assess the correlation of S-100 $\beta$ protein concentrations between plasma and urine samples; and (3) to compare sampling delays between patients with vs. without a detectable S-100 $\beta$ protein concentration for plasma and urine samples.

We conducted this prospective cohort study at the Hôpital de l'Enfant-Jésus du CHU de Québec-Université Laval, a Level 1 trauma center in eastern Quebec. Eligible patients were identified by treating physicians as having sustained an mTBI, defined as a Glasgow Coma Scale score (GCS) of 13-15 at presentation and at least one of the following: confusion or disorientation, loss of consciousness for $30 \mathrm{~min}$ or less, posttraumatic amnesia for less than $24 \mathrm{~h}$ or neurological focal symptoms following a head injury. ${ }^{9}$ We excluded patients if they were assessed more than $24 \mathrm{~h}$ after their injury, were admitted to the hospital, were unable to communicate or did not speak English or French.

Once patients gave their written consent, emergency physicians collected clinical and sociodemographic data and research nurses collected blood and urine samples. Information on time of head trauma and sampling was recorded by research nurses. Information was entered into a secured database and data accuracy was ensured by a research assistant using the patient medical record. Samples were centrifuged, put into three small aliquots and stored at $-20^{\circ} \mathrm{C}$. Within 2 weeks, frozen samples were sent to the central lab and stored at $-80^{\circ} \mathrm{C}$. According to the manufacturers' protocols, S- $100 \beta$ protein levels were measured using Human Protein ELISA kit from Millipore Sigma ${ }^{\circledR}$ (Germany) for plasma samples and from Signalway Antibody ${ }^{\circledR}$ (USA) for urine samples. The detection limits were respectively 2.7 and $15.6 \mathrm{pg} / \mathrm{mL}$.

Our main outcome was the presence of $S-100 \beta$ protein in urine samples, defined as any detectable value as measured by ELISA. Our secondary outcomes were S-100 $\beta$ protein plasma and urine levels within 6 and $24 \mathrm{~h}$ of injury. 
Table 2: Information on $\mathrm{S}-100 \beta$ protein concentrations for detectable values ${ }^{\mathrm{a}}$

\begin{tabular}{l|c|c|c}
\hline Type of sample & \multicolumn{2}{|c|}{ S-100 $\beta$ concentrations $^{\mathbf{c}}$} & \multicolumn{1}{c}{ Elevated values $^{\mathbf{b}}$} \\
\hline & Sampled $<\mathbf{6 h}$ & Sampled $<\mathbf{2 4 h}$ & All patients $(\boldsymbol{n}=\mathbf{5 2})$ \\
\hline Plasma & $n=23 ; 33.3(22.2,64.4)$ & $n=42 ; 34.4(20.0,65.6)$ & $n=7(15.2 \%)$ \\
\hline Urine & $n=18 ; 169.5(84.0,379.0)$ & $n=33 ; 118.0(76.0,262.0)$ & $n=19(41.3 \%)$ \\
\hline
\end{tabular}

${ }^{\mathrm{a}} \mathrm{Limit}$ of detection: plasma $>2.7 \mathrm{pg} / \mathrm{mL}$, urine $>15.6 \mathrm{pg} / \mathrm{mL}$.

${ }^{\mathrm{b}} \geq 100 \mathrm{pg} / \mathrm{mL}$.

${ }^{\mathrm{c}}$ Median (Q1, Q3) in picograms per millilitre (pg/mL).

Table 3: S-100 $\beta$ protein sampling delay ${ }^{\mathrm{a}}$

\begin{tabular}{|c|c|c|c|c|c|c|}
\hline \multirow[t]{2}{*}{ Type of sample } & \multicolumn{5}{|c|}{ Sampling delay ${ }^{\text {b }}$} & \multirow[b]{2}{*}{$p$-values } \\
\hline & All patients & $n$ & Detected $^{\mathrm{c}}$ & $n$ & Non-detected & \\
\hline Plasma $(n=45)$ & $5.5(4.0,11.8)$ & 42 & $5.4(3.8,9.1)$ & 3 & $9.4(14.7,23.3)$ & 0.217 \\
\hline Urine $(n=46)$ & $5.4(4.0,11.8)$ & 33 & $5.3(4.0,14.7)$ & 13 & $5.5(4.5,7.1)$ & 0.913 \\
\hline
\end{tabular}

${ }^{\mathrm{a} U n k n o w n}$ delay in one patient for plasma samples.

${ }^{\mathrm{b}}$ Delay between trauma and plasma or urine sampling in hours (median [Q1, Q3]).

${ }^{\mathrm{c}}$ Detectable values of S-100 $\beta$ protein concentration (limit of detection: plasma $2.7 \mathrm{pg} / \mathrm{mL}$, urine $15.6 \mathrm{pg} / \mathrm{mL}$ ).

${ }^{\mathrm{d}}$ Two-sided Wilcoxon rank sum test.

We presented our descriptive analyses using proportions and medians with their corresponding measures of dispersion for categorical and continuous variables, respectively. Time of sampling and S-100 $\beta$ protein concentrations were right-skewed (Shapiro-Wilk, $p<0.01$ ), we thus compared distributions using Wilcoxon rank sum tests and assessed correlation with the Spearman rank correlation coefficient. We report the present study in accordance with the Strengthening the Reporting of Observational Studies in Epidemiology (STROBE) statement. We performed all analyses with Statistical Analysis System ${ }^{\circledR}$ (SAS Institute Inc., Cary, North Carolina, USA, v. 9.4). The project was approved by the CHU de Québec-Université Laval Research Ethics Board.

Between May 6, 2014 and April 9, 2015, 46 patients were eligible for our study with adequate biological material for laboratory analyses. Among these, 33 (72\%) were males and $37(80 \%)$ were aged between 14 and 54 years old, and 1 person in 2 sustained a concomitant injury (Table 1 ).

S-100 $\beta$ protein concentrations were detectable in $42(91 \%)$ and $33(71 \%)$ patients in plasma and urine, respectively (Table 1). $\mathrm{S}-100 \beta$ protein concentrations in plasma were not correlated with that in urine (Spearman $r=0.002, p=0.99$ ). In plasma, median S-100 $\beta$ protein concentrations in patients sampled within $6 \mathrm{~h}$ were similar to that in patients whose samples were taken within $24 \mathrm{~h}$ of trauma; however, in urine, median S-100 $\beta$ protein concentrations were slightly higher in patients sampled $<6 \mathrm{~h}$ (Table 2). Median delays for plasma and urine sampling in all patients were similar (Table 3 ).

There were some limitations to our study. Our study sample included only 46 patients, but all patients had at least one symptom among amnesia, confusion, loss of consciousness or focal neurological signs, so our conclusions apply to these patients. Limits of detection of the ELISA kits used for plasma and urine differed slightly and any protein concentration below these limits could not be measured. However, $S-100 \beta$ protein was detectable in most plasma samples and $71 \%$ of urine samples and the corresponding $S-100 \beta$ protein values were not correlated with each other. So far, the potential usefulness of S-100 $\beta$ protein has been related to elevated values (e.g. $\geq 100 \mathrm{pg} / \mathrm{mL}$ ) largely above our limits of detection (i.e. 2.7 or $15.6 \mathrm{pg} / \mathrm{mL}$ ). Therefore, more sensitive urine assays would be unlikely to change our results.

According to some authors, S-100 $\beta$ protein levels could be of interest for patients with an mTBI, notably during the acute phase to determine the need to perform a head CT scan to identify intracranial lesions requiring a neurosurgical intervention. 6,10 However, our results suggest that even when they could be measured in urine, S-100 $\beta$ protein concentrations from urine samples were not correlated with those in plasma samples of mTBI patients and are thus unlikely to yield clinically actionable information in an acute ED setting using currently available ELISA technology.

The ideal time frame for sampling remains controversial, but information on kinetic patterns and physiological pathways suggests that it has important clinical consequences. In adult patients with severe TBI, S-100 $\beta$ protein kinetic patterns of serum and urine levels have been shown to differ. In a study conducted by Rodriguez et al., ${ }^{2}$ in both cases, a peak was reached in the first sample within $6 \mathrm{~h}$ of injury. Serum levels gradually decreased until $96 \mathrm{~h}$ while urine levels decreased until $48 \mathrm{~h}$ but increased up to $96 \mathrm{~h}^{2}$ For practical purposes, serum and urine samples are often taken at the same time, even though $\mathrm{S}-100 \beta$ protein physiological pathways suggest temporal differences. Following a TBI, the bloodbrain barrier is often disrupted and proteins are leaked into the serum. Serum half-life of $\mathrm{S}-100 \beta$ protein is estimated to be $30,{ }^{4} 60^{7}$ or even 120 min. ${ }^{8}$ Persistent elevations of S-100 $\beta$ protein levels thus indicate a passive release or an active secretion from damaged tissues. ${ }^{2,8}$ Urine samples taken within $2 \mathrm{~h}$ of injury might be uncorrelated with intracranial injury but we found insufficient evidence to draw any firm conclusions. 
Some authors suggest that if both samples are taken too early (e.g., $<12 \mathrm{~h}$ in severe TBI), serum and urine samples could still be confounded by extracranial S-100 $\beta$ protein influx. ${ }^{8}$ Under these conditions, the serum and urine sampling times that would allow the best potential correlation with patient's diagnosis or prognosis might differ.

In summary, the results of our study suggest that urine samples measured with ELISA technology are unlikely to be as useful as serum samples to measure $S-100 \beta$ protein concentration to guide clinical management of adults with mTBI during the acute phase in the ED. This was the first study to compare S-100 $\beta$ protein levels in plasma and urine in this population. Future studies should assess the relevance of using urine samples with other biomarkers in the ED context.

\section{ACKNOWLEDGEMENTS}

The authors would like to thank Marilyne Dufresne for supervising patient recruitment, Daniel Robin for his support with the database, Françoise Morin and Dounia Hamoudi for laboratory analyses and all emergency physicians of the Hôpital de l'Enfant-Jésus du CHU de Québec-Université Laval for their involvement in this study.

\section{Disclosures}

Natalie Le Sage received a CIHR «Catalyst Grant - Mild Traumatic Brain Injury (\#290457)» for this project. The other authors have no conflicts of interest.

\section{STATEMENT OF AUTHORSHIP}

NL, JF, ME, JMC, LM, PA and JP conceived the study and obtained research funding. NL undertook recruitment of patients and managed data. JF and ABP were responsible for human products and laboratory analyses. NL and PAT provided statistical advice on study design and analysed the data. PAT drafted the manuscript, NL critically revised it and all remaining authors contributed substantially to its final revision. NL takes responsibility for the paper as a whole.

\section{REFERENCES}

1. Ryu WH, Feinstein A, Colantonio A, Streiner DL, Dawson D. Regional variability in the use of CT for patients with suspected mild traumatic brain injury. Can J Neurol Sci. 2009; 36(1):42-6.

2. Rodriguez-Rodriguez A, Egea-Guerrero JJ, Leon-Justel A, et al. Role of S100B protein in urine and serum as an early predictor of mortality after severe traumatic brain injury in adults. Clin Chim Acta; Int J Clin Chem. 2012;414:228-33.

3. Michetti F, Corvino V, Geloso MC, et al. The S100B protein in biological fluids: more than a lifelong biomarker of brain distress. J Neurochem. 2012;120(5):644-59.

4. Hallen M, Karlsson M, Carlhed R, Hallgren T, Bergenheim M. $\mathrm{S}-100 \mathrm{~B}$ in serum and urine after traumatic head injury in children. J Trauma. 2010;69(2):284-9.

5. Jeter CB, Hergenroeder GW, Hylin MJ, Redell JB, Moore AN, Dash PK. Biomarkers for the diagnosis and prognosis of mild traumatic brain injury/concussion. J Neurotrauma. 2013;30(8): 657-70.

6. Unden L, Calcagnile O, Unden J, Reinstrup P, Bazarian J. Validation of the Scandinavian guidelines for initial management of minimal, mild and moderate traumatic brain injury in adults. BMC Med. 2015;13:292.

7. Dash PK, Zhao J, Hergenroeder G, Moore AN. Biomarkers for the diagnosis, prognosis, and evaluation of treatment efficacy for traumatic brain injury. Neurotherapeutics 2010;7(1):100-14.

8. Thelin EP, Nelson DW, Bellander BM. A review of the clinical utility of serum S100B protein levels in the assessment of traumatic brain injury. Acta Neurochir (Wien). 2017;159(2): 209-25.

9. Holm L, Cassidy JD, Carroll LJ, Borg J. Neurotrauma task force on mild traumatic brain INJURY of the WHOCC. Summary of the WHO collaborating centre for neurotrauma task force on mild traumatic brain injury. J Rehabil Med. 2005;37(3):137-41.

10. Zongo D, Ribereau-Gayon R, Masson F, et al. S100-B protein as a screening tool for the early assessment of minor head injury. Ann Emerg Med. 2012;59(3):209-18. 